\title{
BACTERIOLOGICAL STUDIES ON ASCITES IN BROILER CHICKENS
}

\author{
WALID H. HASAN ${ }^{1}$; MOHAMMED A.A. ABD EL-LATIF ${ }^{2}$ AND \\ AHMED H. ABED \\ ${ }^{1}$ Bacteriology, Mycology and Immunology Department, Faculty of Veterinary Medicine, Beni-Suef \\ University, Egypt. \\ ${ }^{2}$ Animal Health Research Institute Dokki, El Fayoum Branch, Egypt.
}

Received: 17 September 2020; Accepted: 1 October 2020

\begin{abstract}
Ascites in poultry is a serious problem for the commercial broiler industry causing great economic losses. In the present study, the prevalence of ascites was studied in 200 broiler chickens. Also, the correlation between ascites and other systemic lesions at the same bird was investigated. Moreover, identification of the causative bacterial agents was conducted focusing on E. coli and Salmonellae isolates. The prevalence rate of ascites in examined broiler chickens was $17 \%$. Ascites without systemic lesion was observed in $10 \%$ of birds while $7 \%$ of birds had ascites associated with other systemic lesions in the internal organs and hepatitis was the most frequent lesion. The bacteriological examination revealed that out of 49 samples collected, a total of 40 bacterial isolates were recovered (1.6\%). Among the recovered isolates, E. coli was the most prevalent isolate $(n=19 ; 47.5 \%)$ followed by Salmonella spp. $(n=10 ; 25 \%)$, Proteus species $(n=8 ; 20 \%)$ and Enterococcus faecalis $(n=3$; 7.5\%). Antibiogram of $E$. coli isolates showed a high sensitivity against colistin sulphate while they were highly resistant to the other antimicrobials. Meanwhile, Salmonella isolates showed high sensitivities to ciprofloxacin and enrofloxacin while they were highly resistant to the other antimicrobials.
\end{abstract}

Keywords: Broiler chickens, ascites, E. coli, Salmonella, antimicrobial susceptibility.

\section{INTRODUCTION}

The term "ascites"; also known as Water Belly, Pulmonary Hypertension and Right Ventricular Hypertrophy, is a disease in an excessive accumulation of serous fluid in a bird's abdominal cavity leading to carcass condemnation (Calnek et al., 1991). Meanwhile, Julian (1990) reported it as a sign or lesion not a disease. The fluid may/or not contain yellow fibrin clots giving it a yellowish colour (Jacob, 2015).

Corresponding author: AHMED H. ABED

E-mail address: aboabedelmasry@yahoo.com, ahmed.moawad@ vet.bsu.edu.eg

Present address: ${ }^{1}$ Bacteriology, Mycology and Immunology Department, Faculty of Veterinary Medicine, Beni-Suef University, Egypt.
Ascites is an economically important problem with high morbidity and mortality affecting mainly broiler chickens all over the world (Tafti and Karima, 2000). It is most commonly recorded in male broilers especially those held at high altitude and those exposed to cold weather (Milsavljevic, 2014). Although it has been reported in broilers raised in high and low altitude areas (Maxwell et al., 1986).

Ascites is a multifactorial etiology leading to complexity of the prevention and controlling of this disorder (Knezevic and Milanka, 1996). Expression of ascites in susceptible individuals may be triggered by variety of managemental, nutritional, environmental and genetic insults that cause pulmonary vascular stress and 
inflammation e.g., ischemia, shear stress, infections (viral, bacterial, parasites), toxins (endotoxin or pollutants), as well as autoimmunity (Julian, 2007; Wick et al., 2010 and Tamosiuniene et al., 2011). Ascites is mostly due to behavioral and metabolic traits in broilers leading to vascular damage, increased vascular hydraulic pressure and/or lymph drainage blockage (Tafti and Karima, 2000). The main causes of ascites in broiler chickens are usually chronic passive congestion which is caused by right ventricular failure (Julian and Wilson, 1986) and hepatic fibrosis secondary to hepatitis (Calnek et $a l .$, 1991) as well as other heart and kidney problems (Milsavljevic, 2014). Also, several situations can affect the occurrence of ascites in broiler chickens including respiratory diseases, atmospheric hypoxia, housing environment, toxins, rapid growth rates, high-energy rations as well as nutritional aspects and feed additives (Julian and Wilson, 1986 and Wideman, 1988).

Many Gram-negative bacterial infections are associated with ascites especially $E$. coli (Blanco et al., 1998; Barnes et al., 2008; Hasan et al., 2010 and Syuhada et al., 2014), Pasteurella multocida; cause of fowl cholera, and Salmonella (Calnek et al., 1997 and Hasan et al., 2010). Other Gramnegative infections including Proteus mirabilis, Pseudomonas spp., Acinetobacter spp., Moraxiella spp. and Yersinia spp. were recorded (Awan, 1997). Lipopolysaccharides (endotoxins) play an important role in induction of ascites by triggering pulmonary hypertension attributable to vasoconstriction (Chapman et al., 2008; Lorenzoni and Wideman, 2008 and Wideman et al., 2009). Moreover, Gram-positive bacteria were also recorded in induction of ascites such as Enterococcus faecalis (Murray, 1990 and Tankson et al., 2001), S. aureus and other coagulase negative staphylococci (CNS) as well as Corynebacterium spp. (Awan, 1997).
Although antimicrobial agents are valuable tools to treat clinical disease and to maintain healthy and productive birds, antimicrobial drug use in livestock production has been implicated as a risk factor in the development and dissemination of drug resistance from livestock production farms (Gosh and LaPara, 2007). Food animals and their production environments are reservoirs of both resistant bacteria and resistance genes that could be transferred to humans either by direct contact between animals and humans or indirectly via the food production chain (WHO, 2011); or as a result of the spread of animal waste on land (Heuer and Smalla, 2007). Therefore, the appropriate antibiotic should better be selected on the basis of its sensitivity which could be detected by laboratory examination.

The present study aimed to investigate the prevalence of ascites in broiler chickens as well as identification of the causative bacterial pathogens.

\section{MATERIALS AND METHODS}

\subsection{Chickens}

A total of 200 diseased Hubbard and Ross broiler chickens of different ages (25 weeks) from different farms in Beni-Suef and El-Fayoum Governorates were subjected to the present study during the period from January 2017 up to December 2017. These chickens were subjected to clinical and postmortem examinations to detect ascites.

\subsection{Samples}

Samples were collected aseptically from 34 broiler chickens suffered from ascites with or without septicaemia signs. A total of 49 samples were collected from the affected tissues. Samples from the ascetic fluids as well as the other internal lesions; airsacculitis, pericarditis and hepatitis, were collected from slaughtered diseased and freshly dead chickens. 


\subsection{Bacteriological examination}

The collected samples were aseptically inoculated into tryptone soya broth and MacConkey broth and incubated aerobically at $37^{\circ} \mathrm{C}$ for $24 \mathrm{hrs}$. Then a loopful of the broth culture was streaked onto tryptone soya agar and MacConkey's agar and incubated aerobically at $37^{\circ} \mathrm{C}$ for 24-72hrs. All the recovered isolates were identified morphologically and biochemically according to schemes described by Collee et al. (1996) and Quinn et al. (2002).

\subsection{Identification of bacterial isolates}

\subsubsection{Morphological and biochemical identification}

All the recovered E. coli and Salmonellae isolates were identified morphologically and biochemically according to Collee $e t$ al. (1996) and Quinn et al. (2002). For Gram negative isolates the following tests were used; oxidase, catalase, indole, methyl red, Voges Proskauer, citrate utilization, urease, $\mathrm{H}_{2} \mathrm{~S}$ production on TSI, nitrate reduction and sugar fermentation. Other nonbiochemical tests including motility test and haemolysis onto blood agar were applied. Meanwhile, Gram positive isolates the following tests were used; catalase, sorbitol and arabinose fermentation and gelatin liquefaction. Other non-biochemical tests including haemolysis on blood agar and Growth on Bile aesculin agar and modified Edward's media were applied.

\subsubsection{Identification by using API20E kit}

The appropriate API kit (API20E, Oxoid) was used for identification of the isolates of Family Enterobacteriaceae members. API strips should only be used to identify pure cultures. It was used according to the manufacturer's instruction.

\subsection{Antibiotic susceptibility test}

All bacterial isolates from ascetic chickens were tested for their antimicrobial susceptibility to 14 different antimicrobial discs including; apramycin $(15 \mu \mathrm{g})$, ciprofloxacin $(15 \mu \mathrm{g})$, cefotaxime sodium $(30 \mu \mathrm{g})$, colistin sulphate $(10 \mu \mathrm{g})$, sulphamethoxazol-trimethoprim

$(1.25+23.75 \mu \mathrm{g})$, doxycycline $\mathrm{HCl}(30 \mu \mathrm{g})$, enrofloxacin $(5 \mu \mathrm{g})$, lincomycin $(10 \mu \mathrm{g})$, spectinomycin $(100 \mu \mathrm{g})$, fosfomycin $(300 \mu \mathrm{g})$, gentamycin $(10 \mu \mathrm{g})$, florophenicol $(30 \mu \mathrm{g}), \quad$ streptomycin $(10 \mu \mathrm{g})$ and spiramycin $(100 \mu \mathrm{g})$ (Oxoid, Basing Stoke, UK). Antimicrobial susceptibility testing was performed using disc diffusion method on Muller Hinton agar according to Clinical and Laboratory Standards Institute (CLSI, 2016). The antimicrobial susceptibility was based on the induced inhibition zones according to the guidelines of the CLSI (2016). Resistance to three/or more antimicrobials of different categories was taken as multidrug resistance (MDR) according to Chandran et al. (2008).

\section{RESULTS}

\subsection{Prevalence of ascites in the examined broiler chickens}

Out of 200 broiler chicken, 34 ones (17\%) showed ascites lesions in PM examination (Table 1). Of them, 20 birds (10\%) had ascites only while 14 birds (7\%) had ascites associated with septicaemic lesions in the internal organs (at least one organ was affected). The affected internal organs included liver $(n=10)$, air sacs $(n=3)$ and pericardium $(n=2)$. On the other hand, 166 $(83 \%)$ had no ascites lesion.

Table 1: Prevalence of ascites in examined broiler chickens.

\begin{tabular}{|c|c|c|c|c|c|c|c|c|}
\hline \multirow{3}{*}{ No. of birds } & \multicolumn{6}{|c|}{ Positive Ascites } & \multirow{2}{*}{\multicolumn{2}{|c|}{$\begin{array}{c}\text { Negative } \\
\text { Ascites }\end{array}$}} \\
\hline & \multicolumn{2}{|c|}{ Ascites only } & \multicolumn{2}{|c|}{ Ascites + Septicaemia } & \multicolumn{2}{|c|}{ Total } & & \\
\hline & No. & $\%$ & No. & $\%$ & No. & $\%$ & No. & $\%$ \\
\hline 200 & 20 & 10 & 14 & 7 & 34 & 17 & 166 & 83 \\
\hline
\end{tabular}

$\%$ : was calculated according to the number (No.) of birds. 


\subsection{Bacteriological examination}

Out of 49 samples collected from different lesions of broilers chickens with ascites; with and without septicaemia, a total of 40 bacterial isolates were recovered with a percentage of $81.6 \%$. Bacterial isolation was distributed as follow; 28 bacterial isolates $(82.4 \%)$ from ascetic fluid samples, $8(80 \%)$ from liver, 2 (66.7\%) from air sacs and $2(100 \%)$ from pericardium. On the other hand, 9 samples (18.4\%) showed negative bacterial isolation (Table 2).

Table 2: Results of bacteriological examination of different samples collected from broiler chickens with ascites/septicaemic lesions.

\begin{tabular}{cccccc}
\hline \multirow{2}{*}{ Samples } & \multirow{2}{*}{$\begin{array}{c}\text { No. of } \\
\text { samples }\end{array}$} & \multicolumn{2}{c}{ Positive bacterial isolation } & \multicolumn{2}{c}{$\begin{array}{c}\text { Negative bacterial } \\
\text { isolation }\end{array}$} \\
\cline { 3 - 6 } & 34 & No. & $\%$ & No. & $\%$ \\
\hline Ascetic fluids & 34 & 28 & 82.4 & 6 & 17.6 \\
\hline Liver & 10 & 8 & 80 & 2 & 20 \\
\hline Airsacs & 3 & 2 & 66.7 & 1 & 33.3 \\
\hline Pericardium & 2 & 2 & 100 & 0 & 0 \\
\hline Total & 49 & 40 & 81.6 & 9 & 18.4 \\
\hline
\end{tabular}

$\%$ : was calculated according to the corresponding number (No.) of the samples.

\subsection{Prevalences of different bacterial pathogens recovered from ascites/septicaemic lesions in broiler chickens.}

The recovered bacterial isolates $(n=40)$ were identified as follow; 19 E. coli isolates with a prevalence rate of $47.5 \%, 10$ Salmonella species (25\%), 8 Proteus species (20\%) and 3 Enterococcus faecalis species $(7.5 \%)$. Concerning ascetic fluid bacterial isolates $(n=28), 12$ isolates $(42.9 \%)$ were E. coli. Moreover, 9
Salmonella (32.1\%), 4 Proteus species (14.3\%) and 3 Enterococcus species $(10.7 \%)$ were identified. Out of 8 bacterial isolates recovered from liver, $4 \mathrm{E}$. coli (50\%), 1 Salmonella species (12.5\%) and 1 Proteus spp. (12.5\%) were identified. Belonging the air sac isolates $(n=2)$, they were identified as E. coli and Proteus species (one, $50 \%$ for each) meanwhile all pericardial isolates $(n=6)$ were $E$. coli (100\%) (Table 3).

Table 3: Prevalences of bacterial pathogens causing ascites and different septicaemic lesions in broiler chickens.

\begin{tabular}{cccccccccc}
\hline $\begin{array}{c}\text { Site of } \\
\text { Samples }\end{array}$ & $\begin{array}{c}\text { No. of } \\
\text { isolates }\end{array}$ & \multicolumn{2}{c}{$\boldsymbol{E}$. coli } & \multicolumn{2}{c}{ Salmonella spp. } & \multicolumn{2}{c}{ Proteus spp. } & \multicolumn{2}{c}{ E. faecalis } \\
\cline { 2 - 10 } & No. & $\mathbf{\%}$ & No. & \% & No. & \% & No. & \% \\
\hline Ascetic fluid & $\mathbf{2 8}$ & 12 & 42.9 & 9 & 32.1 & 4 & 14.3 & 3 & 10.7 \\
\hline Liver & $\mathbf{8}$ & $4^{*}$ & 50 & 1 & 12.5 & 3 & 37.5 & 0 & 0 \\
\hline Air sac & $\mathbf{2}$ & $1^{*}$ & 50 & 0 & 0 & 1 & 50 & 0 & 0 \\
\hline Pericardium & $\mathbf{2}$ & $2^{*}$ & 100 & 0 & 0 & 0 & 0 & 0 & 0 \\
\hline Total & $\mathbf{4 0}$ & $\mathbf{1 9}$ & $\mathbf{4 7 . 5}$ & $\mathbf{1 0}$ & $\mathbf{2 5}$ & $\mathbf{8}$ & $\mathbf{2 0}$ & $\mathbf{3}$ & $\mathbf{7 . 5}$ \\
\hline
\end{tabular}

$\%$ : was calculated according to the corresponding number (No.) of isolates.

*: E. coli isolates from the colisepticaemic lesion of the internal organs (Total No. $=7$ isolates)

\subsection{Antibiotic susceptibility test}

Regarding the results of in-vitro susceptibility testing showed that $E$. coli isolates $(n=19)$ were highly resistant to most of the tested antimicrobials. The highest resistance was recorded against cefotaxime sodium and florophenicol, apramycin, ciprofloxacin and gentamicin (94.7\% for each) followed by enrofloxacin and lincomycin and streptomycin $(89.5 \%$ for each), sulphamethoxazoltrimethoprim and doxycycline $\mathrm{HCl}$, and spiramycin (78.9\%) and finally, fosfomycin $(57.9 \%)$ and spectinomycin $(52.6 \%)$. On the other hand, they were highly sensitive to 
colistin sulphate only $(73.7 \%)$. MDR was detected in all the tested isolates $(100 \%)$.

On the other hand, Salmonella isolates $(n=10)$ were highly sensitive to ciprofloxacin and enrofloxacin $(80 \%)$. On the other hand, they were highly resistant to colistin sulphate, trimethoprim-sulphamethoxazol and lincomycin (80\% for each) followed by spectinomycin, florophenicol, streptomycin and spiramycin (70\%). MDR was detected in all Salmonella isolates (100\%).

\section{DISCUSSION}

Poultry industry has reached great levels of development and became one of the most dynamic areas of agriculture. Poultry is the main protein feed of animal origin for human consumption worldwide (Milsavljevic, 2014) due to efficiency of production cost as well as its short life cycle. In Egypt, great efforts were directed toward the poultry industry to meet the high requirements of animal protein.

Ascites is an economically important problem with high morbidity and mortality mainly affecting broiler chickens over the world (Tafti and Karima, 2000). Ascites is an important metabolic disorder in broiler industry, characterized by hypoxaemia, raised cardiopulmonary system workload (Luger et al., 2003), an excessive accumulation of fluid in peritoneal cavity (Olkowski et al., 2003), hypertrophy of the right ventricle associated with flaccid heart and finally death (Luger et al., 2003). Large number of organs (including the heart, liver, lung, etc.) is involved in the disease (Singh et al., 2013). Although the incidence of ascites in well-managed flocks is very low, it leads to important economic losses to the poultry industry (Balog, 2003 and Bin et al., 2007). It is a major cause of mortality in broilers which can reach; in extreme conditions, up to $25 \%$ although it is frequently 5 to $12 \%$ (Hassanzadeh et al., 2014). Ascites mainly affects fast growing broiler chickens especially males that showed higher levels of ascites than females (Jimenez et al. 1998). Although, it was observed that there was no connection between sex and packed cell volume or ascites heart index, in ascitic birds, and therefore the effect of the sex of the birds is still somewhat unclear (Shlosberg et al. 1997).
In this study, the prevalence of ascites was studied in diseased 200 broiler chickens. Also, the correlation between cellulitis and other systemic lesions of the same bird was studied. Moreover, identification of the causative bacterial agents was conducted focusing on $E$. coli and Salmonella isolates.

The data illustrated in table (1) revealed that the prevalence rate of ascites in examined broiler chickens was $17 \%$. Ascites without systemic lesion was observed in $10 \%$ of birds while $7 \%$ of birds had ascites associated with other systemic lesions in the internal organs (at least one organ). The affected organs included liver $(n=10)$, airsacs $(n=3)$ and pericardium $(n=2)$. On the other hand, $83 \%$ of birds had no ascites lesion. This result was supported by those reported by Muirhead (1987) and Hassanzadeh et al. (2014) who reported that ascites can account up to $25 \%$ of broiler losses. Lower incidence was reported by Maxwell and Robertson (1997) who estimated the incidence of ascites as $4.7 \%$. Moreover, Awan (1997) surveyed in 3 chicken farms. Ascites lesions were found in 0,50 , and $64 \%$ of the birds taken from Farm A, B, and C, respectively. The difference in ascites incidences might be attributed to that ascites is a multifactorial syndrome as environmental, managemental, nutritional, genetic and physiological factors all together are responsible for ascites syndrome (Baghbanzadeh and Decuypere, 2008 and Singh et al., 2013) where the incidence of ascites in well-managed flocks is very low (Balog, 2003 and Bin et al., 2007).

The relationship between ascites and other lesions; especially colibacillosis lesions, of the different organs in broilers appears to be complex and varies from flock to flock. The present results suggested that common predisposing factors may exist for both types of disease. The occurrence of multiple lesions may be underestimated, because other types of lesions in conjunction with ascites may not be detected at the time of inspection, as birds condemned for ascites are not examined further. From other point of view, the present results showed that hepatitis was the most frequently associated with cellulitis while airsacculitis and pericarditis were less frequent.

The previously obtained and discussed results in table (1) were reinforced by the data 
illustrated in table (2) which studied the bacteriological examination of samples collected from different lesions of broiler chickens with ascites either associated with septicaemic lesions or not. Samples were collected from ascetic fluid as well as the other internal lesions; airsacculitis, pericarditis and hepatitis. The results revealed that out of 49 samples collected from different lesions, a total of 40 bacterial isolates were recovered; with a percentage of $81.6 \%$. The isolates were distributed in samples from 34 ascetic fluids, 10 liver, 3 air sacs and 2 pericardium as follow; 28 isolates $(82.4 \%), 8(80 \%), 2(66.7 \%)$ and 2 $(100 \%)$, respectively. On the other hand, $18.4 \%$ of samples showed negative bacterial isolation.

The negative bacterial isolation of some ascetic samples was firstly attributed to non-infectious causes of ascites in broiler chickens due to many interacting factors such as genetics, environment and management (Aftab and Khan, 2005) such as atmospheric hypoxia, housing environment, respiratory diseases, rapid growth rates, high-energy rations, nutritional aspects and feed additives (Julian and Wilson; 1986 and Wideman, 1988). On the other hand, the negative isolation of some ascetic samples may attributed to that some microorganisms might be associated with ascites but not grew on the used culture media and need specific/enriched culture media for their growth including some bacteria as Clostridium perfringens infection (Jacob, 2015 and Hargis, 2018), some fungi including pulmonary aspergillosis; caused by Aspergillus fumigatus, that can cause ascites in broiler chickens due to right ventricular failure (Julian and Goryo, 1990 and Dhama et al., 2013) as well as viral infections (Anjum, 1990) as viruses need tissue culture for their isolation. Additionally, the presence of antibiotic residues may explain false negative bacterial isolation as the withdrawal time was not respected in the herds under study.

Detailed data of the previous results were illustrated in table (3) which showed the results of identification and the prevalences of different bacterial pathogens recovered from broiler chickens with ascites. Among the recovered isolates $(\mathrm{n}=40), E$. coli was the most prevalent as $47.5 \%$ followed b Salmonella species (25\%), Proteus species (20\%) and Enterococcus faecalis species $(7.5 \%)$. Concerning ascetic fluid bacterial isolates $(n=28), 12$ isolates
(42.9\%) were E. coli. Moreover, 9 Salmonella (32.1\%), 4 Proteus species $(14.3 \%)$ and 3 Enterococcus species (10.7\%) were identified.

The current results were supported with those reported E. coli as a cause of ascites (Blanco et al., 1998; Barnes et al., 2008; Hasan et al., 2010 and Syuhada et al., 2014), and also Salmonella spp. (Calnek et al., 1997 and Hasan et al., 2010) while Awan (1997) recorded Proteus spp. and other Gram-negative as causes of ascites. Lipopolysaccharides (endotoxins) play an important role in induction of ascites by triggering pulmonary hypertension attributable to vasoconstriction (Chapman et al., 2008 and Lorenzoni and Wideman, 2008). Moreover, Gram-positive bacteria were also recorded in induction of ascites such as Enterococcus faecalis (Murray, 1990 and Tankson et al., 2001).

Antimicrobial therapy is one of the primary control for reducing both the incidence and mortality associated with avian colibacillosis therefore reducing their enormous losses in the poultry industry (Blanco et al., 1997). However, resistance to existing antimicrobials is widespread and of concern to poultry veterinarians (Allan et al., 1993 and Peighambari et al., 1995). In-vitro antimicrobial susceptibility testing of veterinary pathogens can provide valuable guidance to the veterinarian in the choice of appropriate chemotherapy (Blanco et al., 1997). Moreover, it is very useful to detect the multidrug resistant isolates.

In the present work, all the recovered $E$. coli $(n=19)$ and Salmonella spp. $(n=10)$ were subjected to in-vitro antimicrobial susceptibility tests against 14 different antimicrobial drugs to detect the drug of choice for treatment as well as to detect MDR isolates. The results of antibiogram of $E$. coli isolates showed that a high sensitivity was observed against colistin sulphate only (73.7\%). On the other hand, $E$. coli isolates were highly resistant to the other tested antimicrobial agents. Regarding the result of colistin sulphate susceptibility, it was supported by several previous reports in Egypt and worldwide. In Egypt, the current result was the same with those obtained by Radwan et al. (2020) who applied the in-vitro susceptibility on $80 \mathrm{E}$. coli isolates against 11 antimicrobials and found that $70 \%$ of strains were sensitive to 
colistin meanwhile El-Seedy et al. (2019) found that colistin had the highest sensitivity $(63.6 \%)$. Regarding the increasing incidences of antibiotic-resistance of $E$. coli isolates in such study; these findings were coincided with those recorded by many authors in Egypt (Radwan et al., 2014, 2016 and 2018\& 2020; Awad et al., 2016; Amer et al., 2018; El-Seedy et al., 2019 and Qurani, 2019). Therefore, no single antimicrobial drug was effective by $100 \%$ against $E$. coli isolates, which might be due to development of resistance due to indiscriminate use of antibiotics (Sharada et al., 2001).

Moreover, in the current study, MDR was detected in all E. coli isolates (100\%). Such results agreed also with several previous reports in Egypt and all over the world. In Egypt, Amer et al. (2018); Qurani (2019) and Radwan et al. (2020) found that all E. coli isolates were MDR. Meanwhile, Radwan et al. (2014) recorded MDR in $90.4 \%$ of isolates.

On the other hand, the results of antibiogram of Salmonella isolates revealed high sensitivity to ciprofloxacin and enrofloxacin (80\%). On the other hand, they were highly resistant to the other tested antimicrobial agents. These results coincided with those reported by Yoshida et al. (1993); Yah and Eghafona (2007); Khan et al. (2010) and Fallah et al. (2013) who reported the high resistance of Salmonella isolates chicken against most of these antimicrobials. Moreover, in the present study, MDR was detected in all Salmonella isolates (100\%). Yah and Eghafona (2007) and Fallah et al. (2013) reported lower values of MDRI for Salmonella recovered from chickens; $42.6 \%$ and $34.1 \%$, respectively. Antimicrobial-resistant Salmonella is a public health concern since resistance in Salmonella limits the therapeutic options available to veterinarians and physicians in the treatment of human salmonellosis (Witte, 1998).

\section{CONCLUSION}

Avian ascites is a serious problem for the commercial broiler industry causing great economic losses. The prevalence rate of ascites in examined broiler chickens was $17 \%$. Ascites may be associated with other systemic lesions in the internal organs. E. coli is the most prevalent bacterial agent causing ascites followed by Salmonella spp.

\section{REFERENCES}

Allan, B.J.; van den Hurk, V.V. and Potter, A.A. (1993): Characterization of Escherichia coli isolated from cases of avian colibacillosis. Can. J. Vet. Res.; 57: 146151.

Amer, M.M.; Mekky, H.M.; Amer, A.M. and Fedawy, H.S. (2018): Antimicrobial resistance genes in pathogenic Escherichia coli isolated from diseased broiler chickens in Egypt and their relationship with the phenotypic resistance characteristics. Vet. World, 11 (8).

Anjum, A.D. (1990): Experimental transmission of hydropericardium syndrome and protection against it in commercial broiler chickens. Avian Pathol., 19: 655660.

Awad, A.; Arafat, N. and Elhadidy, M. (2016): Genetic elements associated with antimicrobial resistance among avian pathogenic Escherichia coli. Annals of Clin. Microbiol. Atimi., 15(1): 59.

Awan, M.A. (1997): Systemic Bacterial Infections in Broiler Chickens. Master of Science in Veterinary Science thesis, Oregon State University.

Baghbanzadeh, A. and Decuypere, E. (2008): Ascites syndrome in broilers: physiological and nutritional perspectives'. Avian Pathol., 37(2): 117126.

Balog, J.M. (2003): Ascites syndrome (pulmonary hypertension syndrome) in broiler chickens: Are we seeing the light at the end of the tunnel. Avian Poult. Biol. Rev., 14(3): 99-126.

Barnes, H.J.; Nolan, L.K. and Vaillancourt, J.P. (2008): Colibacillosis. In: Diseases of Poultry, $12^{\text {th }}$ edition. Blackwell publishing. U.S. pp 691-732.

Bin, S.; Keying, Z.; Qiufeng, Z. and Cairong, $W$. (2007): Effects of ascites syndrome in broilers on their growth performances and the availability of energy and nutrients. Frontiers Agric. China, 1(2): 220-223.

Blanco, J.E.; Blanco, M.; Mora, A. and Blanco, J. (1997): Prevalence of Bacterial Resistance to Quinolones and Other Antimicrobials among Avian Escherichia coli Strains Isolated from Septicemic and 
Healthy Chickens in Spain. J. Clin. Microbiol., 35 (8): 2184-2185.

Blanco, J.E.; Blanco, M.; Mora, A.; Jansen, W.H.; Garcìa, V.; Váquez, M.L. and Blanco, J. (1998): Serotypes of Escherichia coli isolated from septicaemic chickens in Galicia (Nortwest Spain). Vet. Microbiol., 61: 229-235.

Calnek, B.W.; Barnes, H.J.; Beard, C.W.; McDougald, L.R. and Saif, Y.M. (1997): Diseases of Poultry. $10^{\text {th }}$ ed. Iowa State University Press, Ames, Iowa. pp. 131140.

Calnek, B.W.; Barnes, H.J.; Beard, C.W.; Reid, W.M. and Yoder, H.W. (1991): Diseases of poultry. $9^{\text {th }}$ ed. Wolfe Publishing LTD. London.

Chandran, A.; Hatha, A.; Varghese, S. and Mony Sheeja, K. (2008): Prevalence of multiple drug resistant $E$. coli serotypes in a tropical estuary, India. Microbes Environ. 23, (2): 153-158.

Chapman, M.E.; Taylor, R.L. and Wideman, R.F. (2008): Analysis of plasma serotonin and hemodynamic responses following chronic serotonin infusion in broilers challenged with bacterial lipopolysaccharide and microparticles. Poult. Sci., 87:116-124.

Clinical and Laboratory Standards Institute (CLSI) (2016): Performance standards for antimicrobial susceptibility testing, $26^{\text {th }}$ Ed. M100-S.

Collee, J.G.; Fraser, A.G.; Marmion, B.P. and Simmons, A. (1996): Practical Medical Microbiology. $14^{\text {th }} \mathrm{Ed}$.

Dhama, K.; Chakraborty, S.; Verma, A.K.; Tiwari, R.; Barathidasan, R.; Kumar, A. and Singh, S.D. (2013): Fungal/Mycotic Diseases of Poultry-diagnosis, Treatment and Control: A Review. Pakistan J. Biological Sci., 16:1626-1640. doi: 10.3923/pjbs.2013.1626.1640. URL: https://scialert.net/abstract/?doi=pjbs.201 3. 1626.1640 .

El-Seedy, F.R.; Abed, A.H.; Wafaa, M.M.H.; Bosila, A.S. and Mwafy, A. (2019): Antimicrobial resistance and molecular characterization of pathogenic E. coli isolated from chickens. J. Vet. Med. Res., 26 (2): 280-292.

Fallah, S.H.; Asgharpour, F.; Naderian, Z. and Moulana, Z. (2013): Isolation and Determination of Antibiotic Resistance
Patterns in Non-typhoid Salmonella spp isolated from chicken. Int. J. Enterpathog., 1(1): 17-21.

Gosh, S. and LaPara, T.M. (2007): The effects of sub-therapeutic antibiotic use in farm animals on the proliferation and persistence of antibiotic resistance among soil bacteria. ISME J, 1: 191-203.

Hargis, B.M. (2018): Ascites Syndrome in Poultry. MSD (Merck Sharp and Dohme Corp.) Veterinary Manual (2018). http://www.msdvetmanual.com/poultry/ miscellaneous-conditions-of-poultry/ ascites-syndrome-in-poultry.

Hasan, A.K.M.R.; Ali, M.H.; Siddique, M.P.; Rahman, M.M. and Islam, M.A. (2010): Clinical and laboratory diagnoses of common bacterial diseases of Broiler and layer chickens. Bangl. J. Vet. Med., 8(2): 107-115.

Hassanzadeh, M.; Buyse, J.; Toloei, T. and Decuypere, E. (2014): Ascites Syndrome in Broiler Chickens: A Review on the Aspect of Endogenous and Exogenous Factors Interactions. J. Poult. Sci., 51(3): 229-241.

Heuer, H. and Smalla, K. (2007): Manure and sulfadiazine synergistically increased bacterial antibiotic resistance in soil over at least two months. Environ Microbiol 9: 657-666.

Jacob, J. (2015): Causes of Ascites in Poultry. http://articles.extension.org/category/poul try.

Jimenez, E.; Lozano, C.; Hernandez, A.; Florez, H. and Pulido, M. (1998): Arterial bloodoxygen partial-pressure, hematocrit, hemoglobin, and cardiac index in broilers at $2600 \mathrm{~m}$ above sea-level. Archivos de Medicina Veterinaria, 30: 67-74

Julian, R.J. (1990): Cardiovascular disease. In: Jordan, F.T.W. (Ed.) Poultry Diseases, $3^{\text {rd }}$ ed., pp. 345-353 (Bailliére Tindall, London, United Kingdom).

Julian, R.J. (2007): The response of the heart and pulmonary arteries to hypoxia, pressure, and volume. A short review. Poult. Sci., 86:1006-1011.

Julian, R.J. and Goryo, M. (1990): Pulmonary aspergillosis causing right ventricular failure and ascites in meat-type chickens. Avian Pathol., 19:643-654.

Julian, R.J. and Wilson, J.B. (1986): Right ventricular failure as a cause of ascites in broiler and roaster chickens. Proceeding 
$4^{\text {th }}$ International Symposium Veterinary Laboratory Diagnostic. pp. 608-611.

Khan, M.; Suryanarayan, P.; Ahmed, M.; Vaswani, R. and Faheem, S. (2010): Antimicrobial susceptibility of Salmonella isolates from chicken meat samples in Dubai, United Arab Emirates. Inter. J. Food Nut. Pub. Hlth., 3(2): 149-159.

Knezevic, N. and Milanka, M. (1996): Diseases of poultry. Belgrade.

Lorenzoni, A.G. and Wideman, R.F. (2008): Intratracheal administration of bacterial lipopolysaccharide elicits pulmonary hypertension in broilers with primed airways. Poult. Sci., 87: 645-654.

Luger, D.; Shinder, D.; Wolfenson, D. and Yahav, S. (2003): Erythropoiesis regulation during the development of ascites syndrome in broiler chickens: A possible role of corticosterone on egg production. J. Anim. Sci., 81: 784-790.

Maxwell, M.H. and Robertson, G.W. (1997): World Broiler Ascites survey 1996. Poult. Int., 36(4):16-30.

Maxwell, M.H.; Robertson, G.W. and Spence, S. (1986): Studies on an ascitic syndrome in young broilers 2. Ultrastructure. Avian Pathol., 15: 525-538.

Milsavljevic, T. (2014): Ascites poultry. J. Dairy Vet. Anim. Res., 1(2):18-20. doi: 10.15406/jdvar:2014.01.00006.

Muirhead, S. (1987): Research defines events leading to the accumulation of fluid in broilers. Feedstuffs.

Murray, B.E. (1990): The life and times of the Enterococcus. Clin. Microbiol Rev., 3:46-65.

Olkowski, A.A.; Wajnarowicz, C.; Rathgeber, B.M.; Abbott, J.A. and Classen, H.L. (2003): Lesions of pericardium and their significance in the aetiology of heart failure in broiler chickens. Res. Vet. Sci., 74: 203-211.

Peighambari, S.M.; Vaillancourt, J.P.; Wilson, R.A. and Gyles C.L. (1995): Characteristics of Escherichia coli isolates from avian cellulitis. Avian Dis.; 39: 116-124.

Quinn, P.J.; Markey, B.K.; Carter, M.E.; Donnelly, W.J.C.; Leonard, F.C. and Maguire, D. (2002): Veterinary Microbiology and Microbial Disease. Published by Blackwell. PP. 113-116.

Qurani, R.O. (2019): Phenotypic and genotypic characterization of Trypsin producing
Escherichia coli isolated from broiler chickens. Ph. D. Thesis (Microbiology), Fact. Vet. Med., Beni-Suef Univ., Egypt.

Radwan, I.A.; Abd El-Halim, M.W. and Abed, A.H. (2020): Genotypic characterization of antimicrobial resistant Escherichia coli isolated from broiler chickens. J. Vet. Med. Res., 27 (2): xxx-xxx.

Radwan, I.A.; Abed, A.H.; Abd Allah, M.M. and Abd El-Latif, M.A.A. (2018): Bacterial pathogens associated with cellulitis in chickens. J. Vet. Med. Res., 25 (1): 6879.

Radwan, I.A.; Abed, A.H.; Abd Al-Wanis, S.A.; Abd El-Aziz, G.G. and El-Shemy, A. (2016): Antibacterial effect of cinnamon and oreganium oils on multidrug resistant Escherichia coli and Salmonellae isolated from broiler chickens. J. Egy. Vet. Med, Ass., 76 (2):169-186.

Radwan, I.A.; Hassan, H.S.; Abd-Alwanis, S.A. and Yahia, M.A. (2014): Frequency of some virulence associated genes among multidrug-resistant Escherichia coli isolated from septicemic broiler chicken. Int. J. Adv. Res., 2(12): 867-874.

Sharada, R.; Krishnappa, G. and Upendra, H.A. (2001): Serological (O) grouping and drug susceptibility of Escherichia coli strains from chicken. Ind. J. Vet., 78: 78-79.

Shlosberg, A.; Elkin, N.; Malkinson, M.; Orgad, U.; Hanji, V.; Bogin, E.; Weisman, Y.; Meroz, M. and Bock, R. (1997): Severe hepatopathy in geese and broilers associated with ochratoxin in their feed. Mycopathologia, 138:71-76.

Singh, P.K.; Shekhar, P. and Kumar, K. (2013): Nutritional and managemental control of ascites syndrome in poultry. Glob. J. Poult. Farm. Vaccinat., 1 (1): 76-82

Syuhada, N.Z.A.; Hair-Bejo, M.; Zakaria, Z.; Omar, A.R. and Khairani-Bejo, $S$. (2014): Isolation of Escherichia coli from various organs of broiler chickens with complicated chronic respiratory disease. ResearchGate. https://www. researchgate.net/ publication/259009442.

Tafti, A.K. and Karima, M.R. (2000): Morphological studies on natural ascites syndrome in broiler chickens. Veterinarski Arhiv, 70 (5):239-250.

Tamosiuniene, R.; Tian, W.; Dhillon, G.; Wang, L.; Sung, Y.K.; Gere, L.; Patterson, A.J.; Agrawal, R.; 
Rabinovitch, M.; Ambler, K.; Long, C.S.; Voelkel, N.F. and Nicolls, M. R. (2011): Regulatory $\mathrm{T}$ cells limit vascular endothelial injury and prevent pulmonary hypertension. Circ. Res., 109:867-879.

Tankson, J.D.; Thaxton, J.P. and VizzierThaxton, $\quad Y$. (2001): Pulmonary Hypertension Syndrome in Broilers Caused by Enterococcus faecalis. Infection and Immunity, 69(10):63186322. DOI: 10.1128/IAI.69.10.63186322.2001.

Wick, G.; Backovic, A.; Rabensteiner, E.; Plank, N.; Schwentner, C. and Sgonc, R. (2010): The immunology of fibrosis: Innate and adaptive responses. Trends Immunol., 31:110-119.

Wideman, R.F. (1988): Ascites in poultry. Monsanto Nutritional Update, 6(2):1-7. Vet. arhiv., 70(5):239-250, 2000.

Wideman, R.F.; Bowen, O.T. and Erf, G.F. (2009): Broiler pulmonary hypertensive responses during lipopolysaccharide- induced tolerance and cyclooxygenase inhibition. Poult. Sci., 88: 72-85.

Witte, W. (1998): Medical consequences of antibiotic use in agriculture Science. 279:996-997.

World Health Organization (WHO) (2011): Tackling antibiotic resistance from a food safety perspective in Europe. Available: http://www.euro.who.int/data/assets/pdf file/0005/136454/e94889.pdf.

Yah, S.C. and Eghafona, N.O. (2007): Plasmids: A vehicle for rapid transfer of antibiotic resistance markers of salmonella species in animals. J. Amer. Sci., 3 (4):86-92.

Yoshida, E.; Saitanu, K.; Jernklinchan, J.; Bangtrakulnonth, A.; Ingkaninun, P. and Poomivses, P. (1993): Comparison of drug resistance and conjugative $\mathrm{R}$ plasmids of Salmonella Typhimurium isolated from humans and poultry. Proc., $11^{\text {th }}$ Int. Symp. World Assoc. Vet. Food Hyg., Thailand, $561-567$.

\section{دراسات بكتريولوجية عن الاستسقاء في بداري التسمين \\ ولبا حمدي حسن ، محمد علي أحد عبل اللطبن ، أحمد حسبن عابل}

E-mail: aboabedelmasry@yahoo.com, ahmed.moawad@vet.bsu.edu.eg Assiut University web-site: www.aun.edu.eg

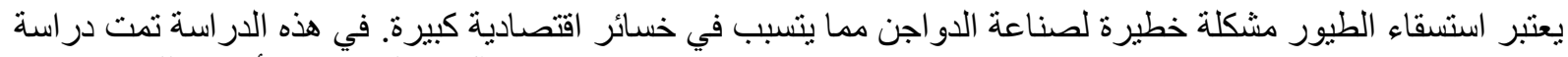

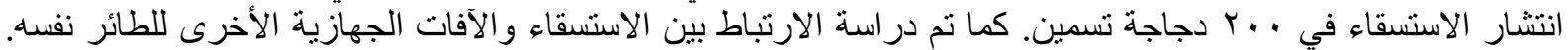

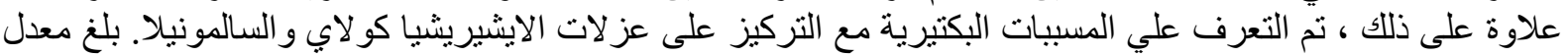

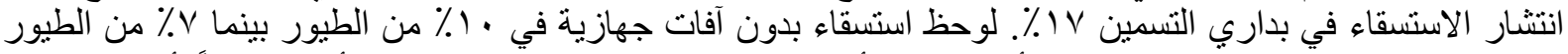

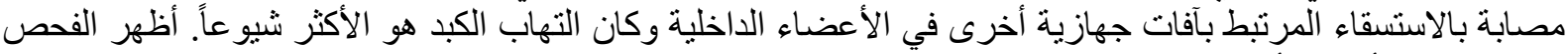

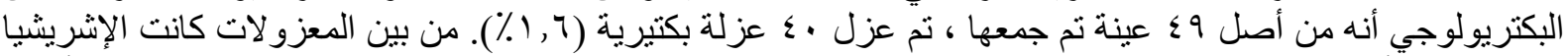

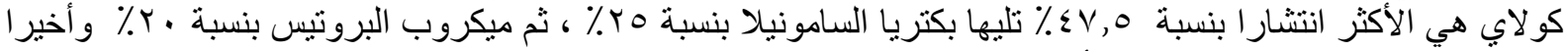

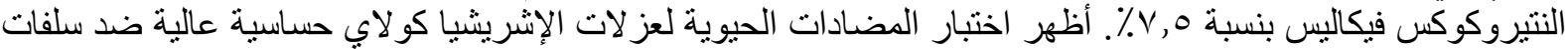
الكوليستين بينما كانت شديدة المقاومة لمضادات الميكروبات الأخرى. في حين أظهرت عزلات لات الات السالمونيلا حساسية عالية

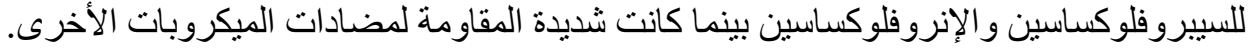

